\title{
Linguistic power bases and structures in Kopstukke (1992) by Jeanne Goosen
}

Barbara Bosch

Department of Afrikaans and Dutch

Rhodes University

GRAHAMSTOWN

What is a language but many words?

Words, only words, but oh what power is contained therein!

(Source unknown)

\section{Abstract \\ Linguistic power bases and structures in Kopstukke (1992) by Jeanne Goosen}

This article argues that in Kopstukke a linguistic analysis of the text can illustrate how specific gendered relations operating within the text are supported by the linguistic fibre of the text.

In Kopstukke the linguistic ecology which is created within the boundaries of the text supports a "postfeminist" perception of gendered relations and relations of dominance in general.

It is argued that by violating certain stereotypical linguistic boundaries (e.g. syntactic structures, linguistic taboos, discourse strategies), barriers operating within the society (which is mirrored in the text) are dismantled.

\section{Introduction}

Despite the fact that from the time of Aristotle there has been a keen sense of linguistic detail in literary studies (Van Peer, 1989:1) the academic study of literary texts is traditionally undertaken from either a linguistic or literary perspective.

Within the structural theoretical framework the scholars Roman Jakobson, Jan Mukarovský and Claude Lévi-Strauss drew attention to the very complex manner in which linguistic patterns play a part in structuring the meanings of a text (Van Peer, 1989:2). 
From the perspective of the textual linguist, who is primarily involved in the study of language in all its variety within a particular contextual framework, this article argues that the literary reading of Kopstukke is supported by the linguistic fibre of the text and that the power-play between the husband and wife is mirrored by and rooted in the language used.

\section{Language, power and gender}

Power is unequally distributed in most societies with the result that the use of powerful language correlates with social power (Zahn, 1969). According to Kress (1989:52):

Language is entwined in social power in a number of ways: it indexes power, expresses power and language is involved wherever there is contention over and challenge to power. Power does not derive from language, but it may be used to challenge power, to subvert it, and to alter distributions of power in the short and in the longer term.

Clearly there is a relationship between power and language with linguistic differences, inter alia, being attributed to factors such as social status and solidarity within a particular environment. Because it is widely accepted that there is an interplay between language and social structure (Graddol \& Swann, 1989:10; O'Barr \& Atkins, 1980) and that the linguistic characteristics of the language used by males and females reflect a particular social order (Coates, 1986:12) "that is in part expressed linguistically" (Thorne \& Henley, 1975:14), a gender-based approach is implemented in this paper in order to unlock certain types of information embedded in Kopstukke. Feminist theorizing has facilitated a process of consciousness-raising conceming power in relationships, but because "power resources are ... not straightforward when it comes to gender relations ... the relationship between power and gender is far from simple" (Davis et al., 1991:17) with researchers emphasizing social status as the key factor in explaining gender-linked differences in language usage (Lakoff, 1975; Fishman, 1980; O'Barr \& Atkins, 1980). The social status of women is influenced by "an ideology of apartheid (between males and females BB) and male monopoly" (Togeby, 1992) resulting in the power the society grants to males affecting and being reflected in conversation and language use because interaction does not take place in a vacuum (Uchida, 1992).

In Kopstukke Goosen addresses the issues of language, power and gender which exist within the boundaries of an intimate relationship. According to Meyer (1991:21) power in loving relationships is "not comparable to power in other relationships, in that loving relations are vehicles of both love and power at the same time". In Kopstukke a gender-linked frame of reference supply the framework from which the linguistic status quo is reviewed: through the use of 
language Goosen attempts to look at society in order to make visible the previously invisible gender and power components.

\section{The title Kopstukke as a linguistic signpost}

The linguistic codes which are operative in the title Kopstukke are important signifiers of the role and function of language in this text.

Kopstukke gesels from which the title is derived, can be interpreted on an idiomatic as well as on a literal level (De Villiers, 1975:134). Kopstukke (gesels) is normally used as an idiomatic expression with the meaning "getting down to brass tacks" (De Villiers \& Gouws, 1989:38). The word kopstukke used within the context of the bedridden main characters who are only able to move their heads and necks, generates a secondary meaning: the koppe (heads) are stukke (pieces) representing a larger (invisible) entity.

Because idiomatic expressions are regarded as a kind of deviation of the language system (cf. De Villiers, 1975:137) the title signals to the reader that what is linguistically overtly stated in the text, should be regarded as elements representing a much larger (implicit and largely unstated) reality. De Villiers (1975:132) argues that, in the case of idiomatic expressions the expression has become a rigid semantic unit: the sections of the idiomatic expression which are not stated overtly in the title cannot be ignored, but should be regarded as an essential part of the title.

It is significant that the element gesels (which is implied in the title) is explicitly omitted from the title Kopstukke, as the whole power structure of this drama hinges on the relevance of communication and non- or miscommunication. The communication process is either supported or obstructed by the conversational routines and topics which are implemented as well as by the symbolic act of the professor's writing down of his experiences but refusing to share it with his wife (Kopstukke:54).

The multiple meanings generated by the title right at the beginning of the drama indicate that the linguistic fibre of the text should not be taken at face value: from a linguistic perspective the language used in Kopstukke is open to interpretations on various levels.

\section{The dialogue in Kopstukke}

The discourse structure and strategies used in Kopstukke serve to support a 
postfeminist $^{1}$ perception of gendered $^{2}$ relations. An awareness of male domination in gendered relations is retained but the complexity of gendered relations, and relations of dominance in general confirms the belief that no singular explanation for relations of power will suffice: within a postfeminist approach there is room for discomforting voices (Rosenfelt, 1991). The "many voices" of both hopes and disappointments of the female character (and by implication of women in general) which is created within the boundaries of the text strongly support a postfeminist reading of Kopstukke.

\subsection{Power play and the dominance of language}

Extensive research has recently been undertaken on the topic of the use of language to establish and sustain power (De Klerk, 1992; Kress, 1989; Kramarae et al., 1984; Thorne \& Henley, 1975). Indeed "(l)anguage is entwined in social power in a number of ways: it indexes power, expresses power and language is involved wherever there is contention over and challenge to power" (Kress, 1989:52). By either adhering to or violating certain stereotypical linguistic boundaries (e.g. syntactic structures, the choice of lexis, discourse strategies), social barriers operating within the text are either supported or dismantled with the result that a "new" social order is established. In a subtle way the linguistic fibre of Kopstukke indicates that language is not only used in an exphicitly communicative sense, but language usage is also linked to power-play with the result that language can be used very effectively to establish and maintain a specific power base.

According to Tannen (1992) male language can be recognized by a high degree of independence, dominance and a desire to retain control. Communication is regarded as being a hierarchical process which involves power struggles with males communicating primarily from a competitive perspective and wanting information (Tannen, 1992:73) and females primarily wanting to establish contact and co-operation (Tannen, 1992:37).

\subsection{The dominating perspective}

The male character in the drama Kopstukke is a well-read university professor

1 According to Millard et al. (1989:247) post-feminism constitutes a "position of having worked one's way through feminist theory to such an extent that the basic tenets of feminism can be taken as read".

2 It has been accepted that gender represents an important division in our society (Graddol \& Swann, 1989:8). 
who secretly tries his hand at writing and who regards his wife as being "benede sy stand" (p. 43). As the drama opens he immediately positions himself in direct opposition to her, obstructs the conversational process ("Hmn", p. 47, "Nou toe nou" p. 52, "Ja", p. 57, "Nee", p. 57) and questions her point of view:

"Vrou: Daar was nie juis iets wat ek kon doen nie.

Man: Maar jy het daarvan gehou. Stry?

Vrou: Ek was bang.

Man: Gmf. Nou sê sy sy was bang." (p. 44)

By not allowing her any initiative in the conversational process ("Ek gee nie 'n moer om wat jy doen nie", p. 48), humiliating her with his use of strong language ("Moenie stront praat nie", p. 46) and his choice of conversational topics (her farting, p. 44) the professor completely dominates his wife on a linguistic level.

Having established his linguistic power base, he tries to maintain his position of dominance by avoiding conversational contact and co-operation (Tannen, 1992) and in doing so manages to subtly disempower her through his use of "malespeak".

His acquisitions directed at her support his position of linguistic domination and throughout the text communication is from a stereotypically male/female perspective. He uses patronizing and intimidating language when addressing her:

"(J)y kan niks doen sonder my nie ... Jy kon nog nooit jou eie besluite neem nie", p. 47; "Jy is sonder identiteit", p. 50; "Jy het verkeerd gelees. Daar is fout met jóú. Wat jy gelees het, staan nie daar geskryf nie", p. 55 .

He victimizes her (e.g. labelling her communicative attempts as being "'n gekerm", p. 49) should she not accept his dominant position. His communication also completely lacks empathy ("Moenie by my kla nie. Kla by Goodness", p. 59).

His contribution to the conversation often consists of short and abrupt statements or directives which are clearly aimed at severing communicative ties ("Gmf. Nou sê sy sy was bang", p. 44; "Nee. Jy is net 'n kla-gat", p. 49; "Ek sê jou mos, vra vir Goodness", p. 59) and obstructing the conversational process (p. 52). He writes down his experiences but refuses to share it with her in any way (p. 54). He further sabotages the communicative process by introducing impolite topics (her farting, reference to his penis, p. 51), requesting 
information or forcing conversation on impolite issues (p. 51-52) and threatening his physical withdrawal (p. 46).

That the male character finds it impossible to communicate with his wife on sexually intimate aspects (p. $52 \& 55$ ) is an indication of his perceived dominant position. According to Tannen (1992:19) intimacy is the key in an environment where the emphasis is on unity and connectedness and where people negotiate linguistically in order to minimalize superiority and differences. This point of view is strengthened by the fact that he is the one commanding the nurse and Goodness: in a status orientated environment the key is independance which is supported by the usage of directives which are aimed at hearers with a lesser status (Tannen, 1992).

It has been acknowledged in sociolinguistic research that politeness routines can reflect power relations between interlocutors (Graddol \& Swann, 1989; Gumperz, 1987) because language usage is entwined in special judgments and prejudices (Wybenga, 1988:87). It is therefore not surprising that the male character is the first to use expletives and indecent terminology. According to De Klerk (1991:157) "expletives carry a powerful emotional and psychological charge, contravening social taboos and [are] frequently used for ... indicating contempt or disregard for [people] ... As a result they have become associated with strength and masculinity in Western cultures". (See also Crosby \& Nyquist, 1977; Holmes, 1984; Key, 1975; McConnell-Ginet et al., 1980; O’Barr \& Atkins, 1980; Spender, 1980.)

\subsection{The dominated perspective}

Gendered features, which according to McConnell-Ginet (1984) convey a sexist world view, are visible in conversational behaviour (Graddol \& Swann, 1989:94). Conversational behaviour results in certain pragmatic strategies typical of a dialogue situation and stereotypical of a certain social order fulfilling important functions in the drama genre.

On the one hand the professor's wife, although being perceived as the "talkative female" (p. 50 \& 56), tries very hard to establish and maintain communicative co-operation ("Die genade het ons uitgespaar, né?", p. 47; "En toe?", p. 49). In order to involve him in the communication process, she excessively uses questions (p. 54).

Her introduction of a new conversational topic (p. 51), her repeated use of as and maar (p. 46, 48, 50,54) and her frequent use of questions when it is her turn to speak, are cues that the female character is on a linguistic level rebelling against her dominated position: "As jy stadiger gery het ... Maar jy wás 
roekeloos ...", p. 46; "Moet jy altyd alles afkraak?" p. 48; "As ek wou, kon ek elke aand gaan dans het", p. 47; "As ons net 'n TV gehad het", p. 48.

When she responds boldly and actually supports the impolite topic which had been introduced by him and also uses expletives (p. $45 \& 56$ ) she violates linguistic norm expectations because the use of impolite language and expletives by females is "generally condemned, seen as presumptuous and inappropriate" (De Klerk, 1991:158). In doing this, she claims social power (albeit uncomfortably, p. 50) because "swearing is (in Western society) associated with powerful language" (De Klerk, 1991:157).

With her use of expletives she actively reacts to male linguistic oppression and victimization on a linguistic level: she had found a way to object to having an indentity imposed on her by the male because it can be argued that "(t)he ... verbal practices of the dominant seem to impose an identity on the dominated that induces them to adopt specific language practices ... Dominant ideology acts as the principle ordering differentiated linguistic "choices"' (Moreau, 1984:60).

The joke which she chooses to tell (Die dokter sê aan 'n vrou wat vermoed dat sy verwagtend is, dat hy vermoed dat dit net ' $n$ wind is. As die dokter haar 'n klompie maande later met 'n stootwaentjie teenkom en vra "En wat het ons hier?", antwoord sy "Dis seker maar 'n poep met 'n kêpsie", p. 45) and the guessing word game which she introduces (p. 57) completely corrupts the male linguistic power base: by moving in on the traditionally male playing fields (the stereotypical perception that females are not supposed to tell dirty jokes (Tannen, 1992: 87)) she erodes the male linguistic power base.

When she uses the racially tainted meid (p. 56) or calls him "jou aap" (p. 57) it can be inferred that a social relationship of domination exists between the interlocutors. Traugott and Pratt (1980:226-227) argue that different forms of address are associated with specific social relationships (specifically establishing and supporting a conversational contract (Wybenga, 1987:38)) and the relative status (hierarchical or otherwise) of the interlocutors: "(d)ie aanspreekvorm kan ... beskou word as die gekodifiseerde representasie van die bestaan van die verhouding tussen spreker en aangesprokene enersyds en die kwalitatiewe aard van die verhouding andersyds" (Jenkinson, 1987:69).

But while rebelling against his dominance and efforts to obstruct the communication process ("Dis jy wat die toutjies trek en ek wat moet spring", p. 47), she is not able to take the communicative initiative completely away from him: after having challenged him in the power game, she still encourages the communication process: "Die genade het ons uitgespaar, né?" (p. 47) in order to establish and maintain a horizontal (and not hierarchical) 
communication process. In doing this she illustrates a commitment to sharing power; she is not interested in turning the "power tables" around completely.

Towards the end of Kopstukke the professor is actively supporting meaningful communication (p. $61 \mathrm{cc}$ ) and politely requesting help (p. 63). His linguistic power-based position at the end of the drama is in direct opposition to his initial obstruction of the communication process and his linguistic behaviour indicates that a change in linguistic dominance has taken place and that he is no longer the partner occupying the more powerful linguistic position.

She, however, does not exploit her more powerful linguistic position in order to create a "new" hierarchical order with the female in command. From her newly achieved position she resists playing the power game, but actively reaches out (uses the term of endearment Mannie, p. 67) and supports her partner in the communication process (p. $63 \& 64$ ).

By means of her choice of language and conversational topics the female character in Kopstukke emphasizes social equality and lack of distance and power in her interaction with the male character; she enforces a system which imposes a symmetry on the male/female relationship in the talk exchange. By doing this she subtly breaks down the traditional male status and the hierarchical power relationship which Tannen (1992:22) maintains is indicative of and condusive to power struggles. At the end of the drama when, after having been linguistically involved in a power struggle throughout the drama, the linguistic power base of "malespeak" has been subtly eroded. The two main characters (male and female) are now harmoniously singing together (p. 69), an act which signals that a different linguistic order had been established.

\section{Conclusion}

This article aims to demonstrate that a high percentage of what is communicated through language has to be "distilled" from that which is not overtly stated: meanings other than or in addition to the obvious meanings of the language used, are conveyed. The specific linguistic codes used in the drama ingeniously support the male and female characterization in the drama: the use of male and female language serve to support and sustain the dominant/dominated gendered tensions existing in the text.

\section{Bibliography}

Coates, J. 1986. Women, men and language. A sociolinguistic account of sex differences in language. London : Longman.

Crosby, F. \& Nyquist, L. 1977. The female register: An empirical study of Lakoff's hypotheses. Language in Society, 6:313-322. 
Davis, Kathy, Leijenaar, Monique \& Oldersma, Jantine (eds.). 1991. The gender of power. London : Sage.

De Klerk, Vivian. 1991. Expletives: Men only? Communication Monographs, 58:156-169.

De Klerk, Vivian. 1992. Power play and the changing face of English. Inaugural lecture. Grahanstown : Rhodes University.

De Villiers, M. 1975. Die semantiek van Afrikaans. Kaapstad : HAUM.

De Villiers, M. \& Gouws, R.H. 1989. Idiomewoordeboek. Kaapstad : Nasou.

Fishman, P. 1980. Conversational insecurity. In: Giles, H. et al. (eds.). Language: Social psychological perspectives. Oxford: Pergamon.

Goosen, Jeanne. 1992. Kopstukke. In: Drie eenakters. Pretoria : HAUMLiterêr. p. 43-69.

Graddol, David \& Swann, Joan. 1989. Gender voices. Cambridge : Basil Blackwell.

Gumperz, John J. 1987. Preface. In: Brown, P. \& Levinson, S.C. Politeness: some universals in language usage. Cambridge : Cambridge University Press. p. 1-50.

Holmes, J. 1984. Women's language: A functional approach. General Linguistics, 24(3):149-178.

Jenkinson, A.G. 1987. Aspekte van voornaamwoorde en verwysing in taalhandelinge. In: Van Jaarsveld, G.N. (red.). Wat bedoel jy? Pretoria : Serva. p. 51-74.

Key, M.R. 1975. Male/Female language. Metuchen, NJ : Scarecrow Press.

Kress, G. 1989. Linguistic processes in sociocultural practice. Oxford : Oxford University Press.

Kramarae, C., Schultz, M. \& O'Barr, W. (eds.) 1984. Language and power. Newbury Park, CA : Sage.

Lakoff, Robin. 1975. Language and woman's place. New York : Harper.

McConnell-Ginet, S. 1984. The origins of sexist language in discourse. Annals of the New York Academy of Sciences, 433:123-135.

McConnell-Ginet, S., Borker, R. \& Furman, N. (eds.). 1980. Women and language in literature and society. New York : Praeger.

Meyer, Joan. 1991. Power and love: Conflicting conceptual schemata. In: Davis, Kathy, Leijenaar, Monique \& Oldersma, Jantine. The gender of power. London: Sage. p. 21-41.

Millard, Elaine, Mills, Sarah, Pearce, Lynne \& Spaull, Sue. 1989. Feminist readings/Feminists reading. Charlottesville : University Press of Virginia.

Moreau, N.B. 1984. Education, ideology and class/sex identity. In: Kramarae, C., Schultz, M. \& O'Barr, W. (eds.) Language and power. Newbury Park, CA : Sage. p. 43-61. 
O'Barr, W. \& Atkins, B. 1980. 'Women's language' or 'powerless language'? In: McConnell-Ginet, S., Borker, R. \& Furman, N. (eds.). Women and language in literature and society. New York : Praeger. p. 93-110.

Rosenfelt, Deborah Silverton. 1991. Feminism, "postfeminism" and contemporary women's fiction. In: Home, Florence (ed.). Tradition and the talents of women. Urbana and Chicago : University of Illinois Press. p. 268-291.

Spender, D. 1980. Man made language. London : Routledge \& Kegan Paul.

Tannen, Deborah. 1992. Je begrijpt me gewoon niet. Hoe vrouwen en mannen met elkaar praten. Amsterdam : Prometheus.

Thorne, B. \& Henley, N. (eds.) 1975. Language and sex: Difference and dominance. Rowley, Mass. : Newbury House Publishers, Inc.

Togeby, Ole. 1992. Is there a separate women's language? International Journal for the Sociology of Language, 94:63-73.

Traugott, Elizabeth C. \& Pratt, Mary L. 1980. Linguistics for students of literature. New York : Harcourt Brace Jovanovich, Inc.

Uchida, Aki. 1992. When "difference" is "dominance": A critique of the "anti-power-based" cultural approach to sex differences. Language in Society, 21(4):547-568.

Van Peer, W. 1989. The taming of the text. Explorations in language, literature and culture. London : Routledge.

Wybenga, D.M. 1987. Wie sal die wa smeer? In: Van Jaarsveld, G.N. (red.) Wat bedoel jy? Pretoria : Serva. p. 35-41.

Wybenga, D.M. 1988. Diskoersanalise en stilistiek. Pretoria : Serva.

Zahn, C.J. 1969. The bases for differing evaluations of male and female speech: evidence from ratings of transcribed conversation. Communication Monographs, 56:59-74. 